\title{
The Utilization of Social Media by Small and Medium Food Vendors in Brunei Darussalam
}

\author{
Meryeme Bouargan, University of Brunei Darussalam, Gadong, Brunei \\ Rabi'atul Adawiyah Haji Abd Halim, University of Brunei Darussalam, Gadong, Brunei \\ Nuruljannah Haji Husaini, University of Brunei Darussalam, Gadong, Brunei \\ Nor Azeem Jusniah, University of Brunei Darussalam, Gadong, Brunei \\ Nur Hazwani Masturah Haji Ahmad, University of Brunei Darussalam, Gadong, Brunei \\ Mohammad Nabil Almunawar, University of Brunei Darussalam, Gadong, Brunei
}

\begin{abstract}
This research examines the factors that contribute to the utilization of social media by the small and medium-sized enterprises (SMEs) operating in the food industry in Brunei Darussalam. It also investigates how social media provides opportunities to SMEs. This research was done using a quantitative method through primary research that was focused on small and medium-sized food vendors in Brunei Darussalam. Survey questions were distributed to food SMEs and vendors, who use social media to assist them in conducting their business, to serve as a guideline to understand how social media networks can lead to positive business outcomes and how understanding key factors may lead to optimizing product portfolios and to discover new opportunities for their business to expand. Based on the authors' research, cost effectiveness was found to influence social media usage among the small and medium food vendors in Brunei. Factors such as trust, interactivity and compatibility, however were not found to be the factors influencing the utilization of social media.
\end{abstract}

\section{KEYWORDS}

Compatibility, Cost Effectiveness, Food Vendors, Interactivity, SME, Social Networks, Transparency, Trust

\section{INTRODUCTION}

Social media has been globally accepted as effective media for communication and collaboration as it provides many advantages which are not offered by other media such as cost-effective, many-tomany interactivity and rich in information content in various forms (multimedia) (Baruah, 2012). As such, it has become an important part of people's lives to connect and keep updated with their relatives and friends. It also opened up new opportunities for individuals to express their creativity in the virtual community. Not only social media has proven to play an essential part in individuals' lives, it also becomes significantly important for small and medium-sized enterprises (SMEs) in 
running their businesses (Dahnil et al., 2014). Given the limited resources and capacities of SMEs, social media is believed to help improve business performances by bringing in new opportunities.

In Brunei Darussalam, social media utilization for businesses seems to be no longer optional. Bruneians can access the Internet on a daily basis. According to the new Digital in 2017 Global Overview report, with the majority of the total population ( 86 percent) using the social media, Brunei Darussalam became the third highest in terms of social media penetration globally (Othman, 2017). Particularly in the food industry, there is an evidently growing interest in the adoption of social media. Businesses use social media as an alternative channel to promote and sell their products, to do research for their product development to optimize their product portfolios and to discover new opportunities for their business to expand. In such manner, it is important for SMEs food industry to have knowledge on the success factors on the utilization social media as this may enhance their ability to make decisions accurately. Learning from mistakes is important. Therefore, various factors that may stop some enterprises from utilizing social media in their business despite their potential benefits need to be properly studied.

The aims of this research are to identify and analyze social media adoption among SMEs in the food industry of Brunei Darussalam and to understand what influences the businesses to use social media in their businesses. The research was carried out with a quantitative method to analyze the responses, supported by other researchers' findings. The study focuses mainly on finding out the reasons why SMEs lean more toward social media to attract their customers and how customers respond to the marketing strategies implemented by these businesses especially now that we are in an era where customers prefer honesty and transparency especially when it comes to food as it is directly related to health and hygiene. Finally, this paper will explore the opportunities provided by social media that could be used by these small and medium enterprises for their growth. It also aims to discover the targeted customers and how the use of social networks such as Facebook and Instagram have become the solution to get new customers.

This paper is organized as follows. Literature review is presented in the next section followed by a discussion on the framework and hypotheses development. Next, we describe research methodology employed followed by data analysis and results of hypotheses testing. We then discuss the result and the final section is conclusions made from the study.

\section{LITERATURE REVIEW}

\subsection{SMEs in Brunei}

In the context of Brunei, SMEs is defined as enterprises having employees ranging from 1 to 100 (Polsaram et al, 2011). Small and medium enterprises (SMEs) play vital part in Brunei Darussalam economic development as a part to diversify the Brunei's economy and create employment. According to International Business Publications (2015), the SMEs in Brunei have contributed to the employment in the private sector for about $92 \%$ and $66 \%$ of the GDP in the non-oil sector. The government has been supporting the growth of SMEs to diversify Brunei's economy. SMEs are encouraged to be creative and exploring the business opportunities locally and outside country as expressed in various Sultan's speech, His Majesty wants his government to give support in the development of SMEs which will allow them to contribute to Brunei's economy (Thambipllai, 2008).

The government has made several actions on the development of SME such as the establishment of Resource Centre which now called as Resource and Standard Centre. It emphasizes on the development of SMEs and provide services to them such as counseling, workshops and others programme that are made specific for SME which are provided by Ministry of Industry and Primary Resources (International Business Publications, 2015). The government established a statutory body called Darussalam Enterprises (DARe) in 2016 to monitor and nurture the growth of local enterprises development. The majority of the board members (81\%) are private sector representation which to ensure that private sector driven the direction and development of SME through DARe. Business 
Support Centre established by DARe in the same year which the centre will provide a single portal or venue for businesses such as give advice and information about business and application of SME programmes, grants and loans (Borneo Bulletin, 2016a).

Banks such as Bank Islam Brunei Darussalam also assists the development of SMEs. They introduced SME $360^{\circ}$ which will assist SMEs and the bank also established one-stop agency which called SME $360^{\circ}$ branch to serve their clients so they could do their businesses and also provide SME-related financial products (Mohammad, 2016). Local SMEs are increasing due to the cube stores where the stores provide small spaces for low rent. The cube stores encourage Bruneian vendors to start their own business with the cube shops as it removes the difficulty of renting the whole shop and it do not need a business license (Borneo Bulletin, 2016b). The cubes available for rent allow the vendors to sell their products such as food, clothes and beauty products. The cube stores can help unemployed people to gain income, as instrument to make their business grow further and make them less reliant on the government.

\subsection{Social Media Adoption for Marketing Purposes}

SMEs are a driving force for the economic growth of many countries such as Malaysia and Indonesia, as it has widely helped fight unemployment and enhanced development in these countries. (Ozigbo \& Ezeaku, 2009). Unfortunately, some may not know how to utilize technology for marketing purposes (Vásquez and Escamilla, 2014). By concentrating on the right platform to campaign effectively, businesses can attract potential customers, influence them to purchase and increase their sales. Social media such as Facebook, Twitter, Snapchat, Instagram and YouTube can be used to expose their businesses for marketing purposes, publicity, and customer relations and market research purposes. Enterprises should keep their efforts manageable and their accounts regularly updated even if maintaining social media takes time (Niven, 2014).

Social media has the potential to be powerful media to engage with consumers and generate brand advocate (Hutter et al., 2009). However, to overcome potential consumers' reluctance, trust needs to be established and reinforced so online word of mouth marketing (e-WOM marketing) can be promoted. With the recent advances in technology, social media and marketing now work closely in the business environment. Using social media increases the search ability of the brand and creates two-way communication with customers, in other words, allows the company to do social network marketing (Öztamur and Karakadilar, 2014).

In Malaysia, the use of Facebook has become increasingly popular to sell products, advertising and marketing at a relatively low cost. Previous studies have found that it is good for businesses to embrace social media such as Facebook due its minimal cost and only requires low IT skills level (Derham et al, 2011). Hassan, S., Nadzim, \& Shiratuddin, (2015) claimed in their studies that the use of social media not only saves money for the company but also impact the company positively by boosting their economic growth.

Another study by Kirtis and Karahan (2011) reveals that social media can strengthen the relationship with customers. Having an online presence makes it possible to reach a much larger audience in a shorter period than the traditional means of communication and all at a cost that is practically null. For many business leaders, social media are seen as a way to strengthen the reputation, visibility and reputation of their organisation (Kaplan \& Haenlein, 2010).

A study developed by Ainin et al. (2015) found that Facebook usage positively impact on SMEs performance outcomes and they also identified factors such as interactivity, compatibility and cost effectiveness influence the SMEs to adopt Facebook for the business activities.

\subsection{Influence of Culture on the Role of Social Media in the Consumer Decision-Making Process}

Marketers can reach potential and current customers through social media, as social media provides the possibility of e-WOM. Goodrich and de Mooij (2013) found that Hofstede's cultural dimensions 
(Hofstede, 1983) could influence purchase decisions through the use of social media. Hofstede's cultural dimensions of individualism/collectivism (IDV/COL) and power distance (PDI) best explain differences in how consumers obtain information and the role of information in the decision-making process. Collectivists tend to acquire information passively through personal contacts and base their buying decisions on opinions of others, feelings, and company trust; whereas people of individualistic culture actively search for information through word of mouth or traditional media. According to the results of the study by Goodrich and de Mooij (2013), marketers in collectivistic culture should make use of social media more as their marketing strategy due to social media playing an important role in forming opinions They also found long/short-term orientation plays a role in differences regarding communication behavior between the businesses and the consumers in explaining variations in trust in online sources of information.

\section{FRAMEWORK AND HYPOTHESES DEVELOPMENT}

From the above literature review, it can be agreed that social media usage helps small businesses to grow through marketing (Neti, 2011). To better understand the factors influencing social media adoption, the research has been inspired by a framework developed by Ainin et al (2015). Ainin's study claimed that previous studies have focused on the impact of the adoption of social media in relation with trust, compatibility, cost effectiveness and interactivity as well as financial and non-financial performance. For that matter, they suggested investigating the extent to which these six factors are correlated with the use of social media by SMEs in the Malaysian market. In the same fashion, we have adapted Ainin's model and used it to explore how factors such as trust, compatibility, cost effectiveness and interactivity influence social media usage in this study in the context of Brunei (Figure 1).

The four factors explored in this research are:

1. Compatibility refers to the degree to which innovation fits with the potential adopter's existing values, previous practices and current needs (Roger, 1983). Previous studies have investigated how compatibility may or may not influence firms to adopt technology in their businesses and have found mixed results regarding the factor compatibility influencing firms decision for technology adoption. The adoption of technology is usually affected by factors such as relative benefit, complexity, compatibility, testability, and observation (Rogers, 1995). Roger's study showed that a combination of these factors influences the adoption of technologies positively. Another study by Davis (1989) has showed that two psychological factors were found through

Figure 1. The research model

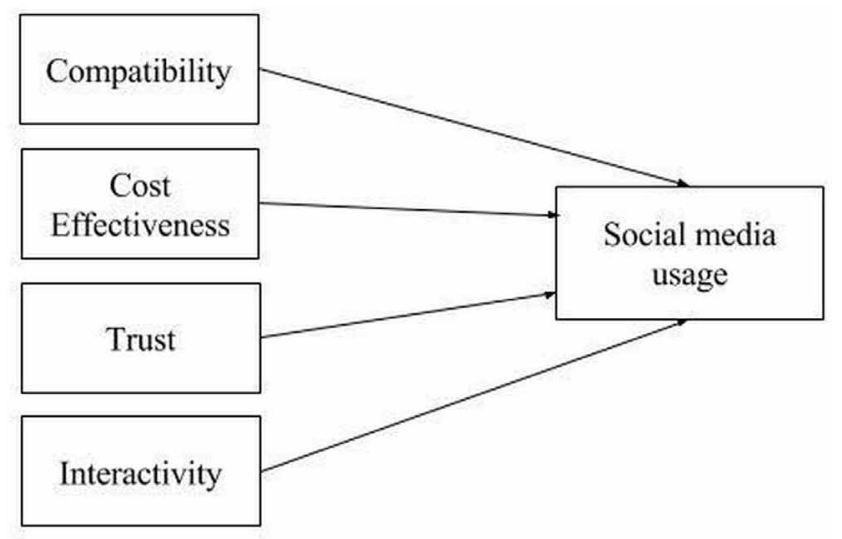


their technology acceptance model (TAM). These factors would determine the adoption of technology ease of use has a greater impact on the adoption of technology: self-efficacy and instrumentality; which leads basically leads to determine the degree of compatibility of working with the said technology (Davis et al., 1989);

2. Cost effectiveness refers to the importance of cost in the adoption and utilization of the technology (Ernst and Young, 2001). Researchers have found that cost effectiveness has a significant influence towards businesses, especially SMEs, regarding technology adoption. In the same fashions, it was found out by Guariglia et al. (2011) that small sized businesses usually struggle with the adoption of new technologies as it would be considered as an extra cost that they may not be able to handle. However, lately, many small companies have managed to improve their business using the Internet. Thanks to the cost effectiveness of Internet technologies. Through the Internet, especially social media, they can promote new products, locate new potential investors, manage their marketing and communications strategies, identify new customers and identify new market niche (Kaplan et al. 1997, Coccia 1997, Hawking, 1997). This only shows how the financial factor can be crucial to SMEs when it comes to adopting new technologies. As social media is relatively cheap to use, organizations are more likely to use social media for marketing and communication purposes (Michaelidou et al., 2011);

3. Trust refers to structural assurance and informational trust in using social media for work-related purposes. According to McKnight et al. (1998), structural assurances refer to the belief that favorable outcomes are likely because of contextual structures, such as contracts, regulations and guarantees. Whereas informational trust is defined as 'a user's belief about the reliability, credibility and accuracy of information obtained from Facebook (Chai et al., 2011). As businesses post information about their organizations, products and services they offer on social media, there is a possibility that there is a need for trust in adopting social media for work-related purposes. Being present on social media should represent a real guarantee of trust to customers. Trust helps increase the business reputation and attract more potential customers (Bauer, Grether \& Leach, 2002). SMEs adoption of social media help them create a bond of trust with consumers. Trust can be achieved by being at the level of customer expectations for instance (Shih, 2009). All of this is the best way to build brand authority or expertise, build trust, and present the business in the best light (Michaelidou et al., 2011);

4. Interactivity refers to the interaction between human and technology regarding the design and implementation of the information systems (Lee and Kozar, 2012). Social media such as Facebook is considered as an interactive media as it enables two-way communication (Mayfield, 2008). Due to interactivity allowed by social media, it might have an influence towards businesses to use social media. In addition to having an Internet presence through a website, social media offers a level of interactivity. It's the fastest and most direct way of communicating with target businesses' goal is to differentiate themselves from the competition (Michaelidou, 2011), attract both suppliers and consumers and build solid relationships with them and finally transform the interactivity into a sale (Shih, 2009). (corrected). In fact, Businesses should interact with their target audience in order to help getting their brand noticed, they must be attracted to quality content. Social media can help collect more information about customers. The idea is to build brand awareness, and to acquire new customers. To do this, more than advertising in the strict sense, the preferred method is to deploy a content strategy. This method is the one that will allow you to position a business in the eyes of their targets, their customers and potential customers most of the time. (Breslauer \& Smith 2009; eMarketer, 2010).

From the factors explained above, following hypotheses were developed to investigate how the above factors influence social media utilization amongst SMEs in Brunei's food sector (see Table 1). 
Table 1. Null and alternative hypotheses for all the variables

\begin{tabular}{|l|l|}
\hline \multicolumn{1}{|c|}{ Item } & \multicolumn{1}{c|}{ Hypotheses } \\
\hline $\mathrm{H}_{1}$ & Compatibility positively influences social media usage \\
$\mathrm{H}_{0,1}$ & Compatibility negatively influences social media usage \\
\hline $\mathrm{H}_{2}$ & Cost effectiveness of social media positively influences social media usage \\
$\mathrm{H}_{0,2}$ & Cost effectiveness of social media negatively influences social media usage \\
\hline $\mathrm{H}_{3}$ & Trust on social media positively influences social media usage \\
$\mathrm{H}_{0,3}$ & Trust on social media negatively influences social media usage \\
\hline $\mathrm{H}_{4}$ & Interactivity of social media positively influences social media usage \\
$\mathrm{H}_{0,4}$ & Interactivity of social media negatively influences social media usage \\
\hline
\end{tabular}

\section{RESEARCH METHODOLOGY}

\subsection{Sampling}

Respondents aimed in this research were mainly the SMEs and local entrepreneurs who use social media such as Instagram, Facebook, WhatsApp, Twitter and Snapchat as their tools to conduct their business. This is because; it is believed that the targeted respondents have a better understanding and would be able to provide reliable data on food industry in Brunei. In this sense, we have handed out 60 questionnaires to be filled by the local entrepreneurs who use social media for their work-related transactions and deals. Questionnaires were distributed on and other were distributed through Google forms. It should be noted that the study aimed for a convenience sampling method which means that all possible subjects of the population have a chance of being included. It is relatively a cost-effective method of data collection.

\subsection{Data Collection}

The questionnaire was created using Google Form platform, which was then circulated through paper survey and social media platform from $7^{\text {th }}$ of April to 16th of April in 2017. From these platforms, respondents could easily access the questionnaire and submit responses directly. These responses were then downloaded from Google Form into Excel and were then analyzed by using SPSS Statistics 20.

\subsection{Instruments}

Primary data collection instrument used for this research is in the form of a questionnaire, which was divided into two (2) sections. The first section looked into the details of respondents where questions such as gender, age, mode of running the business, types of social media used, frequency social media usage and also the reason for their choice of social media usage were asked. In the following section, it is where questions related to the constructs such as trust, interactivity, compatibility and cost effectiveness influencing social media adoption among SMEs in food industry in Brunei Darussalam were asked. As shown in Table 2, the statements were measured using five-point Likert scale items, ranging from 1 = "strongly disagree" to 5 = "strongly agree", and followed by comments section where respondents can give their comments regarding their social media adoption in their business.

Subsequently, secondary data was retrieved from the previous studies in the same area of interest, online journals, research papers and websites; in order to gather and strengthen all of the information needed also as our guidance in the research project. 
Table 2. Operationalization construct

\begin{tabular}{|c|c|c|}
\hline Construct & Construct Definition & Operational Definition \\
\hline $\begin{array}{l}\text { Social Media } \\
\text { Usage }\end{array}$ & $\begin{array}{l}\text { Social Media Usage refers } \\
\text { to how social media help } \\
\text { company to conduct their } \\
\text { businesses. }\end{array}$ & $\begin{array}{l}\text { Please indicate how likely you agree or disagree: } \\
\text { 1. My business uses social media to advertise and promote product and services. } \\
\text { 2. My business uses social media to create brand visibility. } \\
\text { 3. My business uses social media to conduct marketing research. } \\
\text { 4. My business uses social media to get referrals (word of mouth via likes, shares, and } \\
\text { followers). } \\
\text { 5. My business uses social media to communicate with customer. } \\
\text { 6. My business uses social media to develop customer relations. } \\
\text { 7. My business uses social media to conduct customer service activity (interactions with } \\
\text { customer before, during and after purchase). } \\
\text { 8. My business uses social media to feedback of product/services offered. } \\
\text { 9. My business uses social media to reach new customers. } \\
\text { 10. My business uses social media to search for competitor information. }\end{array}$ \\
\hline Trust & $\begin{array}{l}\text { Trust refers to structural } \\
\text { assurance and informational } \\
\text { trust in using social media for } \\
\text { work-related purposes. }\end{array}$ & $\begin{array}{l}\text { 1. Social media provides my business with adequate measures to protect information posted by } \\
\text { my company. } \\
\text { 2. Social media provides my business with a safe environment to transact information. } \\
\text { 3. Social media provides my business with adequate technological measures to deliver information. } \\
\text { 4. Social media allows my business to be trusted. } \\
\text { 5. Social media allows my business to give good quality service. }\end{array}$ \\
\hline Interactivity & $\begin{array}{l}\text { Interactivity refers to the } \\
\text { interaction between human } \\
\text { and technology regarding the } \\
\text { design and implementation of } \\
\text { the information systems }\end{array}$ & $\begin{array}{l}\text { 1. Social media provides my business with features for interactive communication with customers. } \\
\text { 2. Social media provides my business with appropriate number of interactive features (e.g. } \\
\text { graphics, music, etc.). } \\
\text { 3. Social media provides my business with features for clear responses. }\end{array}$ \\
\hline Compatibility & $\begin{array}{l}\text { Compatibility refers to the } \\
\text { degree to which innovation fits } \\
\text { with the potential adopter's } \\
\text { existing values, previous } \\
\text { practice and current needs. }\end{array}$ & $\begin{array}{l}\text { 1. Social media usage is compatible with the company's IT infrastructure (devices, software, } \\
\text { network, etc.). } \\
\text { 2. Social media usage is consistent with the beliefs and values of your business. } \\
\text { 3. Social media usage is consistent with your business strategy. }\end{array}$ \\
\hline $\begin{array}{l}\text { Cost } \\
\text { Effectiveness }\end{array}$ & $\begin{array}{l}\text { Cost effectiveness refers to } \\
\text { the importance of cost in the } \\
\text { adoption and utilization of } \\
\text { Social Media }\end{array}$ & $\begin{array}{l}\text { 1. Social media is more cost effective than other types of marketing or customer service technologies. } \\
\text { 2. My business can avoid unnecessary cost and time by using social media. } \\
\text { 3. Social media saves seller's effort in marketing, branding and customer service. }\end{array}$ \\
\hline
\end{tabular}

\section{DATA ANALYSIS AND RESULTS}

This section presents the analysis of data and the test results for the hypotheses of the study. For this study, Descriptive Statistics and Multiple Regression Analysis were applied for statistical analysis.

\subsection{Background of Respondents}

The sample of this study would be those food vendors who use social media to do their business. About 20 paper-based questionnaires were distributed, but only 15 questionnaires returned. From the survey, we conduct online via Google Forms, we managed to get 45 respondents. Thus, for the data analysis, 60 respondents were selected as the sample size of this study, which gives a response rate of 92.3 percent. The following sections of data analysis will analyze the background of the respondents.

\subsubsection{Gender}

Based from the survey result, majority of the respondents of the sample population were female. 76.7 percent (or 46) respondents were female food vendors, while only 23.3 percent or 14 respondents are male. The data will be illustrated in Figure 2.

\subsubsection{Age}

From our survey results, a majority of the respondents are food vendors from age group 15-34 years old. Only a small number of $3.3 \%$ (or 2) respondents are from the age group 55 years old and above. A small percentage of $18.3 \%$ (or 11) respondents are from age group 18-24 years old, $23.3 \%$ (or 14) 


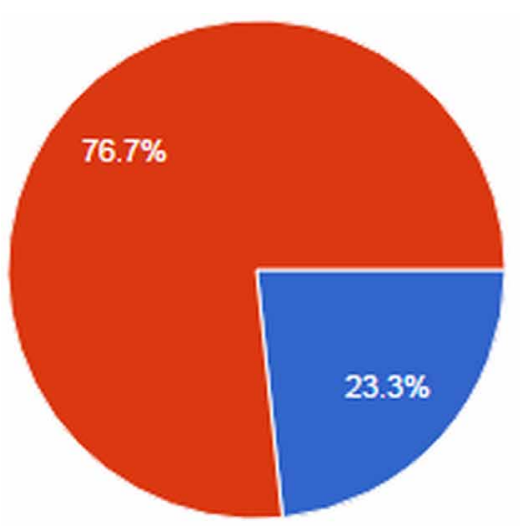

Male

Female

respondents are from age group 35-44 years old and 15\% or (9 respondents) are from age group 4554 years old). Summarised data is shown in Table 3.

\subsubsection{Mode of Running Business}

Based on the data analysis, 22 (36.7 percent) respondents run this business at a full-time basis and 38 (63.3 percent) respondents run this business at a part-time basis. This is as shown on Table 4.

\subsubsection{Social Media Platform Used}

Based on the data analysis, most respondents use more than one social media platform to assist their business. Most respondents use Instagram to assist their business with a percentage of 83.3 percent. 3.3 percent of the respondents use websites; 58.3 percent of the respondents use Facebook; 73.3 percent of the respondents use Whatsapp; 5 percent of the respondents use Twitter and only 1.7 percent of the respondents use Snapchat to assist their business. Table 5 shows the social media platform that the food vendors are using.

\section{Table 3. Respondents' age}

\begin{tabular}{|l|l|l|}
\hline & \multicolumn{1}{|c|}{ Frequency } & Percentage (\%) \\
\hline 18 years old and below & 0 & 0 \\
\hline $18-24$ years old & 11 & 18.3 \\
\hline $25-34$ years old & 24 & 40.0 \\
\hline $35-44$ years old & 14 & 23.3 \\
\hline $45-54$ years old & 9 & 15.0 \\
\hline 55 years old and above & 2 & 3.3 \\
\hline
\end{tabular}

Table 4. Respondents' mode of running business

\begin{tabular}{|l|l|l|}
\hline & \multicolumn{1}{|c|}{ Frequency } & \multicolumn{1}{|c|}{ Percentage (\%) } \\
\hline Full-time & 22 & 36.7 \\
\hline Part-time & 38 & 63.3 \\
\hline
\end{tabular}


Table 5. Respondents' choice of social media platform

\begin{tabular}{|l|l|l|}
\hline & \multicolumn{1}{|c|}{ Frequency } & \multicolumn{1}{c|}{ Percentage (\%) } \\
\hline Instagram & 50 & 83.3 \\
\hline Website & 2 & 3.3 \\
\hline Facebook & 35 & 58.3 \\
\hline WhatsApp & 44 & 73.3 \\
\hline Twitter & 3 & 5 \\
\hline Snapchat & 1 & 1.7 \\
\hline
\end{tabular}

\subsubsection{Frequency of Updating Social Media}

Based on the data analysis, 25 (41.7 percent) of the respondents update their social media several times a day; 19 (31.7 percent) of the respondents update their social media about once a day; 14 (23.3 percent) of the respondents update their social media about 2-3 times a week and 2 (3.3 percent) of the respondents update their social media only once a week. Figure 3 shows how often the respondents update or post on social media.

\subsection{Descriptive Analysis of the Responses and Reliability}

For this study, a reliability test was done to see if there is any item to be eliminated from each variable from the Likert-scale questions in the survey. From the test, as shown on Table 6, all five variables have good value of Cronbach's alpha, as the values are all ranging between $0.6-0.9$. Thus, no items were eliminated and further data analysis were carried out.

Table 6 Summarized results from reliability test and minimum, maximum, mean and standard deviation values of constructs obtained from descriptive statistical analysis.

To calculate the values of minimum, maximum, mean and standard deviation of the scores, a descriptive analysis was done. The above table (Table 6) shows the dimension Usage (dependent variable) has a minimum score of 3.8 and maximum score of 5.0 which are the neutral and maximum score on the Likert-scale. The mean is 4.33 which indicates that most of the respondents gave agree as their answer regarding their social media usage. The standard deviation of the score is 0.399 which shows data are closely clustered around the mean, and are reliable.

Figure 3. Respondents' frequency of updating social media

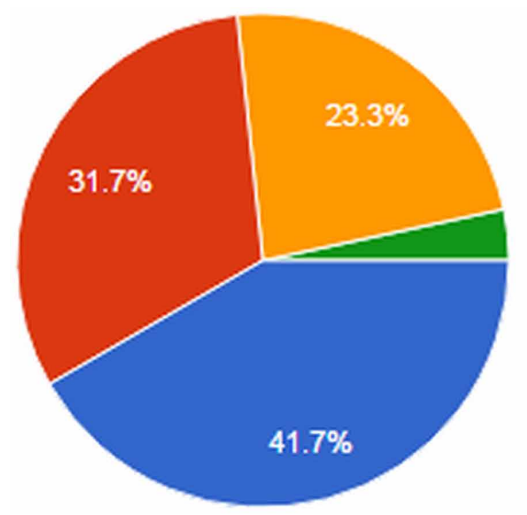

Several times a day

About once a day

2 - 3 times a week

Once a week 
Table 6. Reliability test results

\begin{tabular}{|l|l|l|l|l|l|l|}
\hline \multicolumn{1}{|c|}{ Measure } & No. of Items & $\begin{array}{c}\text { Cronbach's } \\
\text { Alpha, } \boldsymbol{\alpha}\end{array}$ & \multicolumn{1}{|c|}{ Min } & Max & M & SD \\
\hline Usage & 10 & 0.888 & 3.80 & 5.00 & 4.33 & 0.399 \\
\hline Trust & 5 & 0.882 & 3.00 & 5.00 & 3.87 & 0.555 \\
\hline Interactivity & 3 & 0.774 & 3.00 & 5.00 & 4.11 & 0.461 \\
\hline Compatibility & 3 & 0.889 & 3.00 & 5.00 & 3.74 & 0.615 \\
\hline $\begin{array}{l}\text { Cost } \\
\text { Effectiveness }\end{array}$ & 3 & 0.845 & 3.00 & 5.00 & 4.54 & 0.559 \\
\hline
\end{tabular}

For dimension Trust (independent variable), the minimum and maximum scores obtained were 3.0 and 5.0 respectively. The mean score was found to be 3.87, which indicates most respondents are positive with the Trust dimension. The high standard deviation (0.555) indicates high dispersion among the respondent's answers for the questions under Tangibility dimension.

For independent variable of Interactivity, it has a mean score of 4.11, a minimum value of 3.0 and a maximum value of 5.0, which shows that respondents gave a neutral to positive answer for this dimension. The low standard deviation of $46.1 \%$ shows that the dispersion among respondents' answers for questions under this variable is low.

For dimension Compatibility, the minimum and maximum scores obtained were 3.0 and 5.0 respectively, with the mean of 3.74, it shows that the Compatibility dimensions has positive score. The high standard deviation of 0.615 indicates high dispersion among the respondents' answers for questions under Compatibility dimension.

For dimension Cost Effectiveness, it has a mean score of 4.54, a minimum value of 3.0 and maximum value of 5.0. These values indicate that respondents gave a positive answer for questions under this dimension. The high standard deviation percentage of 55.9\% shows the high dispersion of respondents' answers for questions under this independent variable.

From Figure 4, it can be seen that the dimension of cost effectiveness has the highest mean score, which indicates that food vendors in Brunei are adopting social media because of its cost effectiveness.

Figure 4. Mean scores of the five dimensions of the study

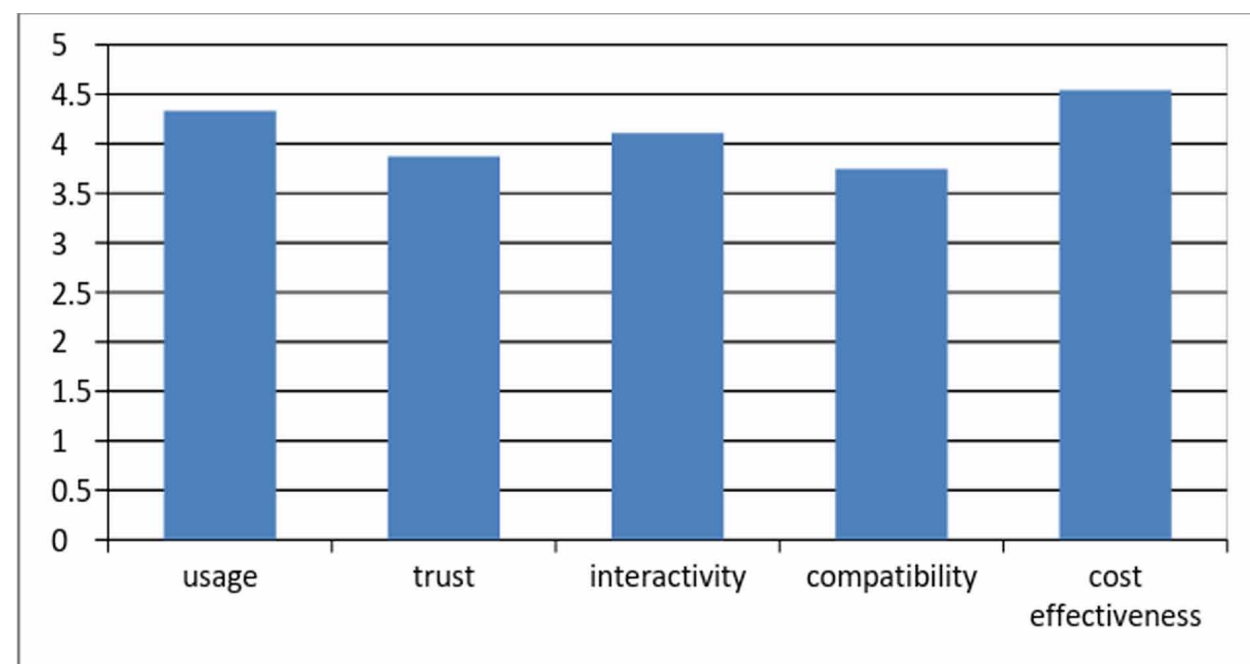


For dimension compatibility on the other hand, it has the lowest mean score of 3.74, which indicates that respondents were mostly neutral about the interactivity of social media.

From the descriptive analysis on the survey responses, we have summarized the result on the frequency table (see Table 7). For Usage, it was found that food vendors who use social media as a platform to assist them in doing their businesses were either mostly positive or neutral regarding their social media usage. We have also found that most of the respondents were positive with the Trust dimension of the social media. As for the measure of Interactivity, a group of respondents felt that the social media platform is very interactive. Under the Compatibility dimension, more than half of the respondents are positive with the compatibility of the social media usage. For the measure of Cost Effectiveness, majority of the respondents are positive and agree that the use of social media is very cost effective in assisting them to conduct their business.

\subsection{Multiple Regression Analysis}

To examine the relationship between social media usage and its four dimensions, we have used multiple regression analyses. As seen from Table 8 of multiple regression data analysis, it was found that the adjusted $\mathrm{R}^{2}$ of our model is 0.176 with the $\mathrm{R}^{2}=0.232$ which indicates the variance in the data. Therefore, we can conclude that the low variance value of $23.2 \%$ shows that the independent variables are not capable in predicting our dependent variable, Usage.

From Table 8, it can be seen that only Cost Effectiveness has a significance value of less than 0.05. Thus, only independent variables of Cost Effectiveness were found to statistically significant.

Table 7. Frequency table of responses for each variable used in the questionnaires

\begin{tabular}{|l|l|l|l|}
\hline \multirow{2}{*}{} & \multicolumn{2}{|c|}{ Frequency } & \multicolumn{1}{|c|}{ Neutral } \\
\cline { 2 - 4 } & Strongly Disagree and Disagree & \multicolumn{1}{|c|}{$\begin{array}{c}\text { Strongly Agree and } \\
\text { Agree }\end{array}$} \\
\hline Usage & $0(0.0 \%)$ & $1(1.7 \%)$ & $59(98.3 \%)$ \\
\hline Trust & $0(0.0 \%)$ & $5(8.3 \%)$ & $55(91.7 \%)$ \\
\hline Interactivity & $0(0.0 \%)$ & $2(3.3 \%)$ & $58(96.7 \%)$ \\
\hline Compatibility & $0(0.0 \%)$ & $19(31.7 \%)$ & $41(68.3 \%)$ \\
\hline Cost Effectiveness & $0(0.0 \%)$ & $1(1.7 \%)$ & $59(98.3 \%)$ \\
\hline
\end{tabular}

Table 8. Results from multiple regression analysis

\begin{tabular}{|c|c|c|c|c|c|c|c|}
\hline & \multirow{2}{*}{$\begin{array}{c}\begin{array}{c}\text { Unstandardized } \\
\text { Estimates }\end{array} \\
\text { B }\end{array}$} & \multirow{2}{*}{$\begin{array}{c}\begin{array}{c}\text { Standard } \\
\text { Error }\end{array} \\
\text { SE }\end{array}$} & \multirow{2}{*}{$\begin{array}{c}\begin{array}{c}\text { Standardized } \\
\text { Estimates }\end{array} \\
\circledR\end{array}$} & \multirow{2}{*}{$\mathbf{t}$} & \multirow{2}{*}{$p$-Level } & \multicolumn{2}{|c|}{$\begin{array}{l}\text { Collinearity } \\
\text { Statistics }\end{array}$} \\
\hline & & & & & & Tol & VIF \\
\hline (constant) & 2.053 & .607 & & 3.379 & .001 & & \\
\hline Trust & .177 & .101 & .246 & 1.746 & .086 & .704 & 1.421 \\
\hline Interactivity & .135 & .119 & .157 & 1.137 & .261 & .734 & 1.361 \\
\hline Compatibility & .035 & .090 & .054 & .389 & .699 & .731 & 1.368 \\
\hline Cost Effectiveness & .200 & .087 & .281 & 2.297 & .025 & .935 & 1.069 \\
\hline $\mathbf{R}^{2}$ & 0.232 & & & df & & $\mathbf{F}$ & 4.149 \\
\hline Adjusted $\mathbf{R}^{2}$ & 0.176 & & Regression & 4 & & & \\
\hline$* p<.05$ & & & Residual & 55 & & & \\
\hline
\end{tabular}


Also, Cost Effectiveness, valued at significance value of $0.025[\mathrm{~F}(4,55)=4.149, \mathrm{p}<.05]$ has the most significant independent variable.

To strengthen the data found on the significance of the independent variables, we can look at the value of beta. The higher the value of beta, the more important the variable is. From the Table 8 , it can be seen that Cost Effectiveness has the highest beta value of $28.1 \%$, which strengthen the significance of the independent variable. This value also indicates that Cost Effectiveness is the largest contributor to our dependent variable, Usage.

From the findings obtained from multiple regression analysis conducted, we could now accept or reject the hypotheses for our study (Table 9). Therefore, hypotheses $\mathrm{H} 4$ (cost effectiveness) is accepted as we have enough evidence to support the hypothesis. However, for hypotheses H1, H2 and $\mathrm{H} 3$, due to not enough evidence to support the hypotheses, null hypotheses $\mathrm{H} 0,1, \mathrm{H} 0,2$ and $\mathrm{H} 0,3$ would have to be accepted:

$\mathbf{H}_{1}$ : There is a positive relationship between trust in social media and the social media usage (NOT SUPPORTED).

$\mathbf{H}_{\mathbf{0}, \mathbf{1}}$ : There is no relationship between trust in social media and the social media usage satisfaction (SUPPORTED).

$\mathbf{H}_{2}$ : There is a positive relationship between interactivity of social media and the social media usage (NOT SUPPORTED).

$\mathbf{H}_{\mathbf{0}, 2}$ : There is no relationship between interactivity of social media and the social media usage satisfaction (SUPPORTED).

$\mathbf{H}_{3}$ : There is a positive relationship between compatibility of social media and the social media usage (NOT SUPPORTED).

$\mathbf{H}_{0,3}$ : There is no relationship between compatibility of social media and the social media usage (SUPPORTED).

$\mathbf{H}_{4}$ : There is a positive relationship between cost effectiveness of social media and the social media usage (SUPPORTED).

\section{DISCUSSION}

\subsection{Cost Effectiveness}

$\mathbf{H}_{4}$ : There is a positive relationship between cost effectiveness of social media and the social media usage (SUPPORTED).

Our results enabled us to understand that cost effectiveness is the only independent variable that is significant to our research. This conclusion is supported by the fact that the majority of respondents confirmed that social media saves them money and time while running marketing action plans as shown in Table 7. As a matter of fact, the cost effectiveness of social media plays an important role

Table 9. Conclusion for hypotheses testing using multiple regression analysis

\begin{tabular}{|l|l|}
\hline \multicolumn{1}{|c|}{ Independent Variable } & \multicolumn{1}{c|}{ Conclusion From Hypothesis Testing } \\
\hline Trust & Hypothesis rejected \\
\hline Interactivity & Hypothesis rejected \\
\hline Compatibility & Hypothesis rejected \\
\hline Cost Effectiveness & Hypothesis accepted \\
\hline
\end{tabular}


in improving SME Key Performance Indicators (KPIs). According to Eckerling (2014), Social media ROI is defined as "a measure of the efficiency of a social media marketing campaign." In fact, SMEs may use social media to improve their profitability through lead generation (leads) and direct sales (customers). In other words, SMEs' may use social media to boost their brand awareness metric while it can improve the turnover - especially when the company has financial constraint (Chong \& Chan, 2012; Alam, 2009) through tackling the customer reach, which leads to a high probability of purchase. Opportunities are now on social networks and it could be a loss to consider omitting social media. Indeed, not all companies can already be present on social networks, but at least they must be concerned to integrate the tool in their communication strategy. The risk of using social media to boost a business performance is very low because social networks cost little, however, not being present can generate a potentially significant shortfall for businesses. Because social media costs only the time, and doesn't require high IT skills (Derham et al., 2011), that's why businesses should get out of their comfort zone and use it even more. In fact, they have to know that they are not supposed to stick to one social medium and that content must be posted regularly. Social networks are booming, undoubtedly. Many companies have chosen to use this new marketing mean to take advantage of its efficient impact. Facebook and its 1.35 billion active users or Twitter and its 284 million users show well that consumers can accept these platforms as marketing tool.

On the other hand, Trust, Interactivity and Compatibility were not significant enough to the importance of social media usage by SMEs. We could assume that low cost is what drives these SMEs to use social media.

\subsection{Trust}

$\mathbf{H}_{\mathbf{1}}$ : There is a positive relationship between trust on social media and the social media usage (NOT SUPPORTED).

Our study found that trust is insignificant factor in social media usage in SMEs. This result is consistent with the results obtained by Wu and Liu (2007) and also Ainin (2015). As interpreted by Ainin, the possible reason for trust to be an insignificant factor is because social media service providers such as Facebook and Instagram are well known with millions of users globally. Due to that reputation, trust may not be an issue for organizations to use social media. Users may feel assured with social media service providers to keep their private information. It is also possible due to social media being cost effective; trust factor might be overlooked and not considered when adopting social media for marketing purposes. However, it should be noted that, trust factor may influence social media usage when businesses have to pay for a certain feature on social media such as the promotion feature. With the promotion feature, a business may be able to reach a certain audience with their advertisement with a cost involved. Then in that situation, trust may become an important factor as there is a possibility of credit card fraud (Wu \& Liu, 2007).

Although our study does not give enough evidence to support the positive relation between trust and the usage of social media and its impact on business, it is considered to be one of the important factors for sustaining a business. It is a tool that helps SMEs build an online brand reputation in a profitable way (Gligorijevic \& Leong, 2011). Trust in social media usually arises from the diversity and quality of information shared by the SME on a particular online platform. Social media allows SMEs to have the opportunity to build a relationship with their customers. It should be noted that they first would show interest in the product, then the business and will definitely share the information using either the tradition or the electronic word of mouth. Credible and transparent information about a business will likely make a customer share it especially if they find it interesting. Finally, it can be said that social networks make it possible to build a balanced relationship between the consumer and the company and because it is a win-win relationship which can lead to a long-term relationship. This could be done for example by selling a product or a service that solves customers' problems (Rust et al., 2010). 


\subsection{Interactivity}

$\mathbf{H}_{2}$ : There is a positive relationship between interactivity of social media and the social media usage (NOT SUPPORTED).

The same goes for Interactivity hypothesis, which is rejected. Social networks are worth nothing if SMEs do not animate their community. The interaction could be in form of offers reserved for members, special events, invitations to events, etc. SMEs are advised to publish everything that makes the life of the company and to create interactivity. By asking questions, creating events, sending invitations and encouraging users to react to each publication, share them and give their opinions. This often allows SMEs to have relevant user experience feedback without resorting to costly and complicated surveys or panels to set up. Furthermore, it is believed that social networks change the way consumers express themselves to the company, as a result of their purchases. This leads us to think that companies should listen and respond to the conversations of Internet users and not ignore them (Rust et al., 2010). Interacting with customers on the Internet provides SMEs with a real-time source of information that can help them better serve their customers and increase their sale performance. To put it in different words, social networks are now an additional medium that companies must include in their business strategy and more specifically in their marketing strategy. A study has shown that this "electronic word-of-mouth" is seen as reliable by consumers and significantly affects a firm's perceived value", (Quesenberry, 2015).

Because social networks cost only the time, more efforts should be invested on social media. It is important to note that a few basic rules must be observed on social networks. Posting trustworthy content regularly and controlling the social media helps customers not to forget about the brand and keep it in their top of mind. That is where the role of a community manager is very significant: it will regulate and animate the community on social networks and ensure the exchanges that occur there. Moreover, it is necessary to be able to identify its target and its objectives to be attained on social media.

\subsection{Compatibility}

$\mathbf{H}_{3}$ : There is a positive relationship between compatibility of social media and the social media usage (NOT SUPPORTED).

As stated above, our findings did not support our hypothesis and rejected the idea that social media is compatible and easily adaptable to SMEs. On the other hand, it was stated by $68 \%$ of our respondents that social media is compatible with their organization, and that it has a positive impact on their business performance. A study stated that the use of Facebook has a significant relation with technology compatibility (Wang et al., 2010). In point of fact, social media platforms like Facebook are trying to attract small businesses by making them userfriendliness. Furthermore, the modern technology and social media also help direct consumers to a certain business, which means that SMES should just work harder to keep up with the upto-date technological trends and integrate them in their business (Accion, 2016). As a matter of fact, it is believed that it is hard for SMEs to work without social media given the circumstances today. Indeed, companies have adapted their management and sales techniques to the opportunities offered by social media, and they would no longer be able to work without them. These media have become the spearhead of some companies. In addition to using these media tools as an advertising showcase, brands have the ability to interact very easily with Internet users via information, images or videos, thus enabling loyalty to be fast to earn. 


\section{CONCLUSION}

Social media is widely used among small and medium enterprises for various reasons. As a matter of fact, Internet has shaken consumption patterns and challenged the functioning of most sectors.

Our aim was to investigate the use of social media within these small and medium entities. After reviewing and analyzing all the collected data and results, our research has revealed that the only factors that matters most to our sample that in Small and medium enterprises in Brunei is costeffectiveness. Concerning trust, compatibility and interactivity, our research revealed that they had no positive correlation with our dependent variable. However, even though these above-mentioned variables were not supported by our study, this does not mean that our results are completely true because not all companies care mostly about making profit, but they can be driven by building a strong image and be closer to their employees and customers. As a matter of fact, this study can be expanded further by testing other sectors such as tourism and banking services for instance in order to gain a broader understanding about the use of these variables within these sectors.

Building up a strong marketing strategy through social media is an ever-ending process and it does not have a typical "how-to" manual that lets businesses learn how to use it over night. It thus appears that the image of SMEs is closely linked with the use of social networks due to its cost effectiveness. Without these networks, some companies would never have been able to make themselves known so quickly thanks to their interactivity on Facebook or Twitter, and other social media. We live in a world with a wide usage of mobile phones. Everything is done through Internet today. The world is radically changing and there is a need to create awareness among business owners that they have to embrace the digital transformation. This certainly requires being on track of what the regularly changing customer needs.

\section{LIMITATIONS}

One of the limitations encountered during this research was mainly during the data collection. In fact, many interviewees and respondents refused to give away some information for privacy or due to professional secrecy. Furthermore, some resources (business owners, business experts, social media experts) did not always have the opportune time to receive us, for various reasons.

On the other hand, surveys are always subject of bias. We opted to question both consumers and SMEs in order to have a broad view on impact of the social media on SMEs. The questionnaires used in this study were detailed in order to to prevent the reluctance of respondents to answer. One last difficulty was that older people are sometimes unfamiliar to responding to online questionnaires, which made the data collection take longer than expected. Finally, we've been only able to reach 60 SMEs to respond to our questionnaire. A larger sample could have been more useful to our research and enable us to achieve more accurate results, 


\section{REFERENCES}

Adams, M. (2014). Three Ways To Build Customer Trust. Forbes.com. Retrieved from https://www.forbes.com/ sites/yec/2014/04/22/three-ways-to-build-customer-trust/\#4be1cf5822b8

Adapting To The Latest Technology Trends For Your Business. (2016). Accion. Retrieved from http://us.accion. org/business-resources/articles-videos/adapting-latest-technology-trends-your-business

Ainin, S., Naqshbandi, M. M., Moghavvemi, S., \& Jaafar, N. I. (2015). Facebook usage, socialization and academic performance. Computers \& Education, 83, 64-73. doi:10.1016/j.compedu.2014.12.018

Ainin, S., Parveen, F., Moghavvemi, S., Jaafar, N. I., \& Mohd Shuib, N. L. (2015). Factors influencing the use of social media by SMEs and its performance outcomes. Industrial Management \& Data Systems, 115(3), 570-588. doi:10.1108/IMDS-07-2014-0205

Alam, S. (2009). Adoption of internet in Malaysian SMEs. Journal of Small Business and Enterprise Development, 16(2), 240-255. doi:10.1108/14626000910956038

Baruah, T. D. (2012). Effectiveness of Social Media as a tool of communication and its potential for technology enabled connections: A micro-level study. International Journal of Scientific and Research Publications, 2(5), 1-10.

Bauer, H. H., Grether, M., \& Leach, M. (2002). Building customer relations over the Internet. Industrial Marketing Management, 31(2), 155-163. doi:10.1016/S0019-8501(01)00186-9

Borneo Bulletin Yearbook. (2016a). Darussalam Enterprise (DARe). Retrieved from http://borneobulletinyearbook. com.bn/the-way-of-life-2/

Borneo Bulletin Yearbook. (2016b). SMEs Surging Ahead. Retrieved from http://2016.borneobulletinyearbook. com.bn/files/assets/basic-html/page-135.html\#

Chai, S., Das, S., \& Rao, H. R. (2011). Factors affecting bloggers' knowledge sharing: An investigation across gender. Journal of Management Information Systems, 28(3), 309-342. Retrieved from http://www.tandfonline. com/doi/abs/10.2753/MIS0742-1222280309

Chong, A. Y.-L., \& Chan, F. T. (2012). Structural equation modeling for multi-stage analysis on radio frequency identification (RFID) diffusion in the health care industry. Expert Systems with Applications, 39(10), 8645-8654. doi:10.1016/j.eswa.2012.01.201

Coccia, S. M. (1997). Leveling the playing field. Medical Marketing \& Media, 32, 30-37.

Dahnil, M. I., Marzuki, K. M., Langgat, J., \& Fabeil, N. F. (2014). Factors influencing SMEs adoption of social media marketing. Procedia: Social and Behavioral Sciences, 148, 119-126. doi:10.1016/j.sbspro.2014.07.025

DanialNorjidi. (2016, March 24). DARe striving to improve business environment. Borneo Bulletin. Retrieved from http://www.borneobulletin.com.bn/dare-striving-to-improve-business-environment/

Davis, F. D. (1989). Perceived usefulness, perceived ease of use, and user acceptance of information technology. Management Information Systems Quarterly, 13(3), 319-340. doi:10.2307/249008

Davis, F. D., Bagozzi, R. P., \& Warshaw, P. R. (1989). User acceptance of computer technology: A comparison of two theoretical models. Management Science, 35(8), 982-1003. doi:10.1287/mnsc.35.8.982

Derham, R., Cragg, P., \& Morrish, S. (2011). Creating value: an SME and social media. In PACIS 2011 Proceedings. Academic Press. Retrieved from http://aisel.aisnet.org/pacis2011/53

Eckerling, D. (2014). How to Measure Social Media ROI. Social Media ROI. Retrieved from http://www. socialmediaexaminer.com/measure-social-media-roi/

Ernst and Young. (2001). Advancing with e-commerce. Retrieved from www.noie.gov.au

Gligorijevic, B., \& Leong, B. (2011). Trust, Reputation and the Small Firm: Building Online Brand Reputation for SMEs. In Proceedings of the Fifth International AAAI Conference on Weblogs and Social Media (pp. 494597). AAAI Press. 
Goodrich, K., \& de Mooij, M. (2013). How 'social' are social media? A cross-cultural comparison of online and offline purchase decision influences? Journal of Marketing Communications, 20(1/2), 1-14. Retrieved from https://www.mariekedemooij.com/articles/goodrich_demooij_2013_journal_marketingcommunications.pdf

Guariglia, A., Liu, X., \& Song, L. (2011). Internal finance and growth: Micro econometric evidence on Chinese firms. Journal of Development Economics, 96(1), 79-94. doi:10.1016/j.jdeveco.2010.07.003

Hassan, S., Nadzim, S. Z. A., \& Shiratuddin, N. (2015). Strategic use of social media for small business based on the AIDA model. Procedia: Social and Behavioral Sciences, 172, 262-269. doi:10.1016/j.sbspro.2015.01.363

Hawking, P. (1997). The implications of Internet telephony to small businesses in Australia'. In Conference Proceedings from SEAANZ Annual Conference.

Hofstede, G. (1983). National cultures in four dimensions: A research-based theory of cultural differences among nations. International Studies of Management \& Organization, 13(1-2), 46-74. doi:10.1080/00208825 .1983 .11656358

Hutter, K., Hautz, J., Dennhardt, S., \& Füller, J. (2013). The impact of user interactions in social media on brand awareness and purchase intention: The case of MINI on Facebook. Journal of Product and Brand Management, 22(5/6), 342-351. doi:10.1108/JPBM-05-2013-0299

International Business Publications. (2016). Brunei Investment and Business Guide. Washington, DC: Author.

Kaplan, A. M., \& Haenlein, M. (2010). Users of the world, unite! The challenges and opportunities of Social Media. Business Horizons, 53(1), 59-68. doi:10.1016/j.bushor.2009.09.003

Kaplan, T. E., Johnson, R. W., Pearce, C. G., \& George, G. (1997). The strategic role of communication technology in small business: Where we are and where we should be going. American Business Review, 15(1), 86-91.

Kirtis, A. K., \& Karahan, F. (2011) To be or not to be in Social Media arena as the most cost-efficient marketing strategy after the global recession. In the Proceeding of Social and Behavioral Sciences, pp. 260-268, 7 th International Strategic Management Conference. doi:10.1016/j.sbspro.2011.09.083

Lee, Y., \& Kozar, K. (2012). Developing a theory of website usability: An exploratory study to identify constructs and nomological networks. Decision Support Systems, 52(2), 450-463. doi:10.1016/j.dss.2011.10.004

Mayfield, A. (2008). What is social media? Icrossing. Retrieved from http://www.icrossing.com/uk/sites/default/ files_uk/insight_pdf_files/What\%20is\%20Social\%20Media_iCrossing_ebook.pdf

McKnight, D. H., Cummings, L. L., \& Chervany, N. L. (1998). Initial trust formation in new organizational relationships. Academy of Management Review, 23(3), 473-490. doi:10.5465/amr.1998.926622

Michaelidou, N., Siamagka, N. T., \& Christodoulides, G. (2011). Usage, barriers and measurement of social media marketing: An exploratory investigation of small and medium B2B brands. Industrial Marketing Management, 40(7), 1153-1159. doi:10.1016/j.indmarman.2011.09.009

Mohammad, L. (2016, September 23). BIBD launches first SME 360 branch. Retrieved from http://www. ei.gov.bn/Lists/Industry\%20News/NewDispForm.aspx?ID=98\&ContentTypeId=0x0100585AA17FA637114 E870034FE25016A22

Neti, S. (2011). Social media and its role in marketing. International Journal of Enterprise Computing and Business Systems, 1(2), 1-15.

Niven, R. (2014, April 16). How small businesses are making the most of social media to grow. Retrieved from https://www.theguardian.com/small-business-network/2014/apr/16/social-media-smes-growth

OECD. (2012). Food and the Tourism Experience: The OECD-Korea Workshop. Paris: OECD Publishing. doi:10.1787/9789264171923-

Othman, A. (2017, August 8). Surge in mobile phone, broadband penetration in Brunei. Borneo Bulletin. Retrieved from http://borneobulletin.com.bn/surge-mobile-phone-broadband-penetration-brunei/

Ozigbo, N. C., \& Ezeaku, P. (2009). Adoption of information and communication technologies to the development of small and medium scale enterprises (SMEs) in Africa. Journal of Business and Administrative Studies, 1(1), 1-20. doi:10.4314/jbas.v1i1.47894 
Öztamur, D., \& Karakadılar, İ. S. (2014). Exploring the role of social media for SMEs: As a new marketing strategy tool for the firm performance perspective. Procedia: Social and Behavioral Sciences, 150, 511-520. doi:10.1016/j.sbspro.2014.09.067

Polsaram, P., Kulsiri, P., Techasermsukkul, L., Htwe, T. D., \& Kwanchainond, K.(2011). A Survey Research Project on "Small and Medium Enterprises Development Policies of 4 ASEAN Countries": Brunei Darussalam, Cambodia, Lao PDR, Myanmar. ASEAN. Retrieved from http://www.asean.org/storage/images/documents/ SME\%20Policies\%20in\%204\%20ASEAN\%20Countries\%20-\%20Brunei\%20Darussalam.pdf

Quesenberry, K. A. (2015, November). Conducting a Social Media Audit. Harvard Business Review. Retrieved from https://hbr.org/2015/11/conducting-a-social-media-audit

Rogers, E. M. (1983). Diffusion of Innovations. New York, NY: Free Press.

Rust, R. T., Moorman, C., \& Bhalla, G. (2010, January). Rethinking Marketing. Harvard Business Review, 94-101. Retrieved from https://hbr.org/2010/01/rethinking-marketing

Shih, C. (2010). The Facebook Era: Tapping Online Social Networks to Market. Sell, and Innovate. Pearson Education.

Thambipillai, P. (2008). Brunei Darussalam: Making a Concerted Effort. Southeast Asian Affairs, 89-104.

Vásquez, G. A. N., \& Escamilla, E. M. (2014). Best practice in the use of social networks marketing strategy as in SMEs. Procedia: Social and Behavioral Sciences, 148, 533-542. doi:10.1016/j.sbspro.2014.07.076

Wang, Y. M., Wang, Y. S., \& Yang, Y. F. (2010). Understanding the determinants of RFID adoption in the manufacturing industry. Technological Forecasting and Social Change, 77(5), 803-815. doi:10.1016/j. techfore.2010.03.006

$\mathrm{Wu}, \mathrm{J} .$, \& Liu, D. (2007). The effects of trust and enjoyment on intention to play online games. Journal of Electronic Commerce Research, 8(2), 128-140. Retrieved from https://www.researchgate.net/publication/228668939_The_ effects_of_trust_and_enjoyment_on_intention_to_play_online_games 


\section{APPENDIX}

\section{Social Media Adoption in Food Industry Among SMEs in Brunei Darussalam}

We are postgraduate students from University Brunei Darussalam (UBD) under the Faculty of School of Business and Economics. The purpose of conducting this survey is a part of our research, to gain an in depth understanding as well as to identify and analyse social media adoption in food industry among SMEs in Brunei Darussalam.

All responses will be kept confidential for academic purposes only. Your honest opinion and cooperation are highly appreciated. Thank you in advance for participating and helping us in our research.

\section{Section A: Respondent's Background}

1. Age (please specify):

2. Gender (please tick one):
[ ] Female

[ ] Male

3. Occupation (you may tick more than one):
[] Employed
[ ] Unemployed
[ ] Self-employed
[ ] Student

4. Social media platform used (you may tick more than one):
[ ] Facebook
[] Twitter
[ ] Instagram
[ ] Other (please specify):

5. How often do you use social media (please tick one):

[ ] Several times a day

[ ] 2-3 times a week

[ ] About once a day

[ ] Once a week 


\section{Section B: Factors Influencing Social Media Adoption in Food Industry Among SMEs in Brunei Darussalam}

Please rate your satisfaction according to the given situation.

1- SOCIAL MEDIA USAGE (refers to how social media help company to conduct business)

\begin{tabular}{|c|c|c|c|c|c|}
\hline QUESTIONS & $\begin{array}{l}\text { Strongly } \\
\text { Disagree }\end{array}$ & Disagree & Neutral & Agree & $\begin{array}{c}\text { Strongly } \\
\text { Agree }\end{array}$ \\
\hline $\begin{array}{l}\text { 1. My company use social media to advertise and } \\
\text { promote product and services }\end{array}$ & 1 & 2 & 3 & 4 & 5 \\
\hline $\begin{array}{l}\text { 2. My company use social media to create brand } \\
\text { visibility }\end{array}$ & 1 & 2 & 3 & 4 & 5 \\
\hline $\begin{array}{l}\text { 3. My company use social media to conduct } \\
\text { marketing research }\end{array}$ & 1 & 2 & 3 & 4 & 5 \\
\hline $\begin{array}{l}\text { 4. My company use social media to get referrals } \\
\text { (word of mouths via shares and followers in } \\
\text { social media) }\end{array}$ & 1 & 2 & 3 & 4 & 5 \\
\hline $\begin{array}{l}\text { 5. My company use social media to communicate } \\
\text { with customers }\end{array}$ & 1 & 2 & 3 & 4 & 5 \\
\hline $\begin{array}{l}\text { 6. My company use social media to develop } \\
\text { customer relations }\end{array}$ & 1 & 2 & 3 & 4 & 5 \\
\hline $\begin{array}{l}\text { 7. My company use social media to conduct } \\
\text { customer service activity (interactions with } \\
\text { customers before, during and after a purchase) }\end{array}$ & 1 & 2 & 3 & 4 & 5 \\
\hline $\begin{array}{l}\text { 8. My company use social media to receive } \\
\text { feedback of products/services offered }\end{array}$ & 1 & 2 & 3 & 4 & 5 \\
\hline $\begin{array}{l}\text { 9. My company use social media to reach new } \\
\text { customers }\end{array}$ & 1 & 2 & 3 & 4 & 5 \\
\hline $\begin{array}{l}\text { 10. My company use social media to search for } \\
\text { competitor information }\end{array}$ & 1 & 2 & 3 & 4 & 5 \\
\hline
\end{tabular}

2- TRUST IN SOCIAL MEDIA (refers to the believe in the reliability, truth, ability and strength of social media)

\begin{tabular}{|c|c|c|c|c|c|}
\hline QUESTIONS & $\begin{array}{l}\text { Strongly } \\
\text { Disagree }\end{array}$ & Disagree & Neutral & Agree & $\begin{array}{c}\text { Strongly } \\
\text { Agree }\end{array}$ \\
\hline $\begin{array}{l}\text { 1. Social media provide my company with } \\
\text { adequate measures to protect information posted } \\
\text { by my company }\end{array}$ & 1 & 2 & 3 & 4 & 5 \\
\hline $\begin{array}{l}\text { 2. Social media provide my company with a safe } \\
\text { environment to transact information }\end{array}$ & 1 & 2 & 3 & 4 & 5 \\
\hline $\begin{array}{l}\text { 3. Social media provide my company with } \\
\text { adequate technological measures to deliver } \\
\text { information }\end{array}$ & 1 & 2 & 3 & 4 & 5 \\
\hline 4. Social media allows my company to be trusted & 1 & 2 & 3 & 4 & 5 \\
\hline $\begin{array}{l}\text { 5. Social media allows my company to give good } \\
\text { quality of service }\end{array}$ & 1 & 2 & 3 & 4 & 5 \\
\hline
\end{tabular}


3- INTERACTIVITY THROUGH SOCIAL MEDIA (refers as a key and distinguished factor that impacts users' response to social media)

\begin{tabular}{|c|c|c|c|c|c|}
\hline QUESTIONS & $\begin{array}{l}\text { Strongly } \\
\text { Disagree }\end{array}$ & Disagree & Neutral & Agree & $\begin{array}{c}\text { Strongly } \\
\text { Agree }\end{array}$ \\
\hline $\begin{array}{l}\text { 1. Social media provides my company with } \\
\text { features for interactive communication with } \\
\text { customers }\end{array}$ & 1 & 2 & 3 & 4 & 5 \\
\hline $\begin{array}{l}\text { 2. Social media provides my company with } \\
\text { appropriate number of interactive features (eg: } \\
\text { graphics, music, etc.) }\end{array}$ & 1 & 2 & 3 & 4 & 5 \\
\hline $\begin{array}{l}\text { 3. Social media provides my company with } \\
\text { features for vivid responses }\end{array}$ & 1 & 2 & 3 & 4 & 5 \\
\hline
\end{tabular}

4- COMPATIBILITY IN SOCIAL MEDIA (refers to the degree to which innovation fits with the potential adopter's existing values, previous practices and current needs)

\begin{tabular}{|c|c|c|c|c|c|}
\hline QUESTIONS & $\begin{array}{l}\text { Strongly } \\
\text { Disagree }\end{array}$ & Disagree & Neutral & Agree & $\begin{array}{c}\text { Strongly } \\
\text { Agree }\end{array}$ \\
\hline $\begin{array}{l}\text { 1. Social media usage is compatible with the } \\
\text { company's IT infrastructure (devices, software, } \\
\text { network, etc.) }\end{array}$ & 1 & 2 & 3 & 4 & 5 \\
\hline $\begin{array}{l}\text { 2. Social media usage is consistent with the } \\
\text { company's beliefs and values }\end{array}$ & 1 & 2 & 3 & 4 & 5 \\
\hline $\begin{array}{l}\text { 3. Social media usage is consistent with the } \\
\text { company's business strategy }\end{array}$ & 1 & 2 & 3 & 4 & 5 \\
\hline
\end{tabular}

\section{5- COST EFFECTIVENESS OF SOCIAL MEDIA (refers to the importance of cost in the adoption and utilization of social media)}

\begin{tabular}{|c|c|c|c|c|c|}
\hline QUESTIONS & $\begin{array}{l}\text { Strongly } \\
\text { Disagree }\end{array}$ & Disagree & Neutral & Agree & $\begin{array}{c}\text { Strongly } \\
\text { Agree }\end{array}$ \\
\hline $\begin{array}{l}\text { 1. Social media is more cost effective than } \\
\text { other types of marketing or customer service } \\
\text { technologies }\end{array}$ & 1 & 2 & 3 & 4 & 5 \\
\hline $\begin{array}{l}\text { 2. My company can avoid unnecessary cost and } \\
\text { time by using social media }\end{array}$ & 1 & 2 & 3 & 4 & 5 \\
\hline $\begin{array}{l}\text { 3. Social media saves employees effort in } \\
\text { marketing, branding and customer service }\end{array}$ & 1 & 2 & 3 & 4 & 5 \\
\hline
\end{tabular}

\section{6- PERFORMANCE (refers to how social media can have an impact on businesses)}

\begin{tabular}{|c|c|c|c|c|c|}
\hline QUESTIONS & $\begin{array}{l}\text { Strongly } \\
\text { Disagree }\end{array}$ & Disagree & Neutral & Agree & $\begin{array}{l}\text { Strongly } \\
\text { Agree }\end{array}$ \\
\hline $\begin{array}{l}\text { 1. Sales transactions increase with the help of } \\
\text { social media }\end{array}$ & 1 & 2 & 3 & 4 & 5 \\
\hline $\begin{array}{l}\text { 2. Sales volume increases with the help of social } \\
\text { media }\end{array}$ & 1 & 2 & 3 & 4 & 5 \\
\hline $\begin{array}{l}\text { 3. Number of customers increase with the help of } \\
\text { social media }\end{array}$ & 1 & 2 & 3 & 4 & 5 \\
\hline
\end{tabular}




\section{Section C: Comments}

Any comments that you would like to add regarding the adoption of social media in food industry among SMEs in Brunei Darussalam?

Meryeme Bouargan holds a bachelor degree in Business Administration (focus: Marketing and Communications) from al Akhawayn University in Ifrane and a Master degree in Management from the University of Brunei Darussalam. Her current research interests include e-business, social media, marketing and consumer behavior.

Rabi'atul Haji Abd Halim received her first degree in Chemical Engineering at the University of New South Wales, Australia in 2015. She is currently in the final semester of her Master of Management programme at University of Brunei Darussalam. Her research interests include e-Government, Cross-Cultural Management, Strategic Management, as well as Human Resource Management. She participates in various volunteering activities and enjoys art and photography.

Nor Azeem Jusniah holds a BA in Historical Studies from the Universiti Brunei Darussalam. He earned his master's degree in Management from the same university in 2018. His areas of interest include Human Resource Management, Strategic Management, History, and International Relations. He loves travelling, taking photos of nature, watching documentary, and learning foreign languages.

Nur Hazwani Masturah Binti Haji Ahmad completed her Bachelor of Business in Technology Management in Universiti Teknologi Brunei, in 2016. Previously, in 2013, she received her Higher National Diploma in Business Management from the same university. Currently, she is still undergoing master's in management in Universiti Brunei Darussalam, since August 2016. Areas of interest includes, Human Resource and Management, Entrepreneurship Development, Business Strategy, Change Management, E-Business, Technology and Innovations, E- Government, Mathematics, Statistics, Economic Development and Public Sector Management.

Mohammad Nabil Almunawar is currently a Senior Assistant Professor at School of Business and Economics, Universiti of Brunei Darussalam (UBD), Brunei Darussalam. He received his bachelor's degree in 1983 from Bogor Agricultural University, Indonesia, master Degree (MSc Computer Science) from the Department of Computer Science, University of Western Ontario, London, Canada in 1991 and Ph.D. from the University of New South Wales (School of Computer Science and Engineering, UNSW) in 1998. Dr Almunawar has published more than 80 papers in refereed journals, books, book chapters and international conferences. He has more than 25 years teaching experiences in the area computer and information systems. His overall research interests include applications of IT in Management, Electronic Business/Commerce, Health Informatics, information security, social networks and cloud computing. He is also interested in object-oriented technology, databases and multimedia retrieval. 